ORNL/TM-13740

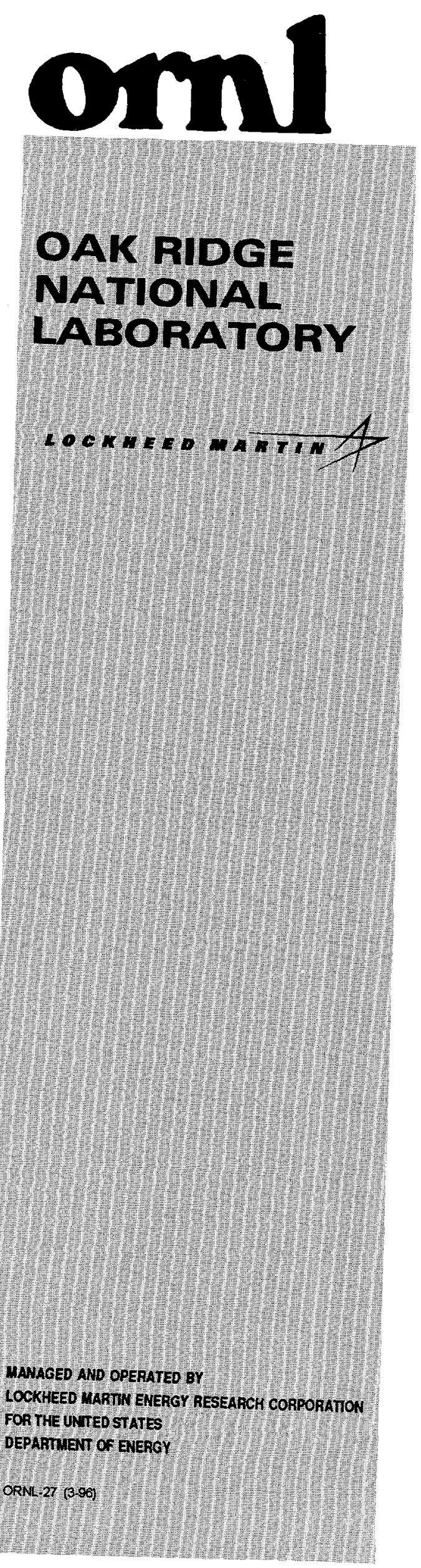

\title{
Batch Tests with IONSIV® IE-911 and a Simulant of the Savannah River Site "Average" Supernatant: Distribution Ratios vs Time
}

\author{
R. D. Hunt \\ K. K. Anderson \\ J. L. Collins \\ D. D. Lee \\ ZECEIVED \\ FEB 221999 \\ OSTI
}


This report has been reproduced from the best available copy.

Reports are available to the public from the following source.

National Technical Information Service

5285 Port Royal Road

Springfield, VA 22161

Telephone 703-605-6000 (1-800-553-6847)

TDD 703-487-4639

Fax 703-605-6900

E-mail orders@ ntis.fedworld.gov

Web site http://www.ntis.gov/ordering.htm

Reports are available to U.S. Department of Energy (DOE) employees, DOE contractors, Energy Technology Data Exchange (ETDE) representatives, and International Nuclear Information System (INIS) representatives from the following source.

Office of Scientific and Technical Information

P.O. Box 62

Oak Ridge, TN 37831

Telephone 423-576-8401

Fax 423-576-5728

E-mail reports@adonis.osti.gov

Web site http://www.osti.gov/products/sources.html

Reports produced after January 1, 1996, are generally available via the DOE Information Bridge.

Web site http://www.doe.gov/bridge 


\section{DISCLAIMER}

This report was prepared as an account of work sponsored by an agency of the United States Government. Neither the United States Government nor any agency thereof, nor any of their employees, make any warranty, express or implied, or assumes any legal liability or responsibility for the accuracy, completeness, or usefulness of any information, apparatus, product, or process disclosed, or represents that its use would not infringe privately owned rights. Reference herein to any specific commercial product, process, or service by trade name, trademark, manufacturer, or otherwise does not necessarily constitute or imply its endorsement, recommendation, or favoring by the United States Government or any agency thereof. The views and opinions of authors expressed herein do not necessarily state or reflect those of the United States Government or any agency thereof. 


\section{DISCLAIMER}

Portions of this document may be illegible in electronic image products. Images are produced from the best available original document. 
Chemical Technology Division

\title{
BATCH TESTS WITH IONSIV® IE-911 AND A SIMULANT OF THE SAVANNAH RIVER SITE “AVERAGE” SUPERNATANT: DISTRIBUTION RATIOS Vs TIME
}

\author{
R. D. Hunt \\ K. K. Anderson \\ J. L. Collins \\ D. D. Lee
}

Date Published: February 1999

\author{
Prepared by the \\ OAK RIDGE NATIONAL LABORATORY \\ Oak Ridge, Tennessee 37831-6285 \\ managed by \\ LOCKHEED MARTIN ENERGY RESEARCH CORP. \\ for the \\ U.S. DEPARTMENT OF ENERGY \\ under contract DE-AC05-96OR22464
}




\section{CONTENTS}

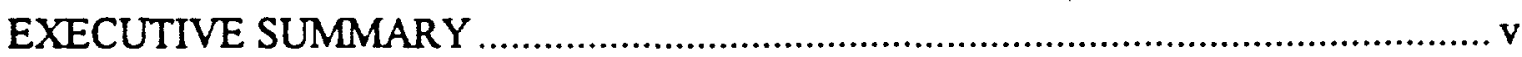

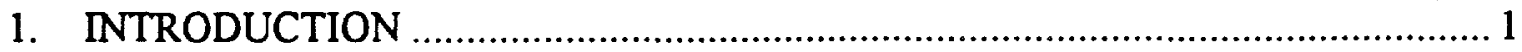

2. SAMPLES

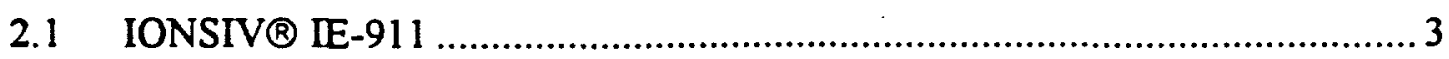

2.2 Simulant of the "Average" SRS Supernatant ........................................ 3

3. EXPERIMENTAL PROCEDURES

3.1 Water Content................................................................................. 4

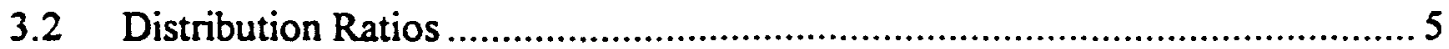

3.3 Maximum Concentration of Soluble Strontium ....................................... 6

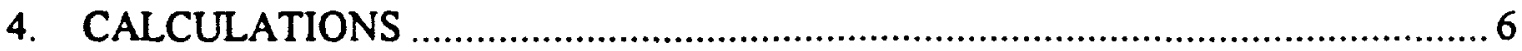

5. RESULTS

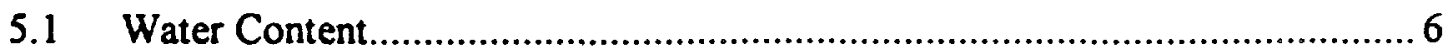

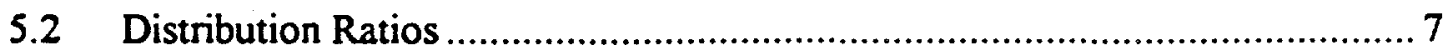

5.3 Maximum Concentration of Soluble Strontium ........................................9

6. DISCUSSION

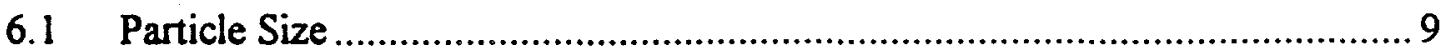

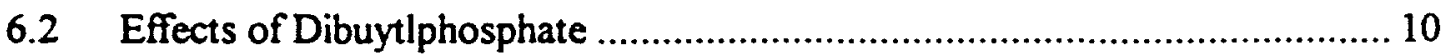

6.3 Actual Vs Predicted Equilibrium D Values ........................................ 11

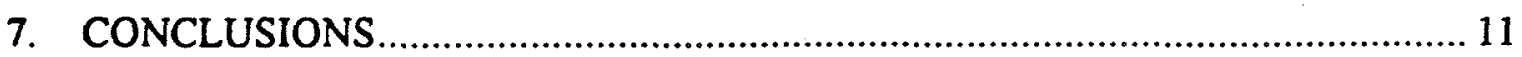

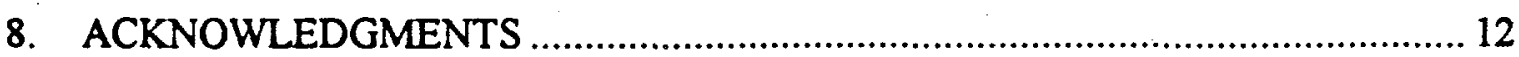

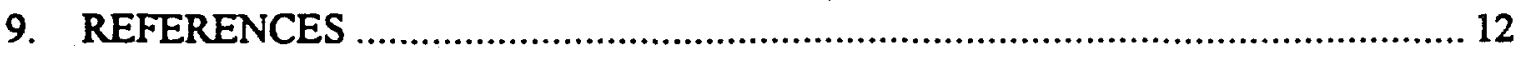

Appendix. WORKSHEETS FOR THE PREPARATION OF THE

SIMULANT OF THE “AVERAGE” SRS SUPERNATANT ............... 14 


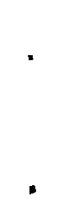




\section{EXECUTIVE SUMMARY}

The production of nuclear materials at the Department of Energy's Savannah River Site (SRS) has generated millions of gallons of radioactive wastes. The primary radionuclide in the liquid wastes or supernatants is ${ }^{137} \mathrm{Cs}$. Nearly all the ${ }^{137} \mathrm{Cs}$ must be removed before the supernatants can be immobilized. Problems during full-scale cesiumremoval operations at the SRS have led to an evaluation of cesium-removal technologies by the High-Level Waste Salt Disposition Team. After an initial screening of all potential alternatives, crystalline silicotitanate (CST), an inorganic ion exchanger, was chosen as one of the leading candidates.

Since nearly all the CST tests have been performed on supernatants from other sites, batch tests were conducted to determine the performance of the engineered form of CST, IONSIV® IE-911, with a simulant of the "average" SRS supernatant. The distribution ratio (D) results from the batch tests clearly indicated that IONSIV® IE-911 can be very effective in the removal of cesium from the simulant of the "average" SRS supernatant. The variability between the different production runs of IONSIV® IE-911 was very small; the $168-\mathrm{h}$ D results for the "as received" samples were 2149 and $2253 \mathrm{~mL} / \mathrm{g}$. However, the variability between the different batches of IONSIV® IE-911 increased after the CST was treated with $\mathrm{NaOH}$ and $\mathrm{H}_{2} \mathrm{O}$ prior to the batch tests. The $168-\mathrm{h} \mathrm{D}$ values for the "treated" samples ranged from 1454 to $2032 \mathrm{~mL} / \mathrm{g}$. The predicted D results from the equilibrium model were comparable to the 168-h experimental results with the "as received" samples of CST. Other tests demonstrated that increases in temperature and particle size can significantly decrease the performance of the IONSIV® IE-911. In particular, the equilibrium model predicted that a temperature increase from 25 to $30^{\circ} \mathrm{C}$ would decrease the $\mathrm{D}$ value from 2340 to $2060 \mathrm{~mL} / \mathrm{g}$. Unlike sample preparation, temperature, and sample size, the presence of the organics did not impact the $D$ results.

Finally, the maximum concentration of soluble strontium in the simulant of the "average" SRS supernatant was $0.37 \mathrm{ppm}$. This low concentration of strontium should not significantly reduce the performance of the CST. 


\section{INTRODUCTION}

The Department of Energy (DOE) is required by law to treat and safely dispose of the radioactive wastes from its nuclear weapon production activities. The primary radionuclide in the DOE liquid wastes or supernatants is ${ }^{137} \mathrm{Cs}$. At the Savannah River Site (SRS), the In-Tank Precipitation (ITP) process was selected as the baseline technology to remove ${ }^{137} \mathrm{Cs}$ from the supernatants, which are stored in underground storage tanks. In the ITP process, tetraphenylborate reacts with the water-soluble cesium to form a precipitant. The treated supernatant can then be immobilized in grout or saltstone and stored in vaults at the SRS. However, problems were encountered during the full-scale ITP processing.

These difficulties have led to the evaluation of alternative technologies and/or concepts to the currently configured ITP process. The High-Level Waste Salt Disposition Team at the SRS is currently performing this assessment. After an initial screening of all potential alternatives, the Salt Disposition Team selected four primary options to evaluate further before the final down-selection. Crystalline silicotitanate (CST), an inorganic ion exchanger, was chosen as one of the leading alternatives. Since nearly all of the CST tests have been performed on supernatants from Hanford and Oak Ridge, the Salt Disposition Team has requested that personnel at the SRS and Oak Ridge National Laboratory (ORNL) determine the performance of the engineered form of CST, IONSIV® IE-911, with actual and simulated SRS supernatants.

Previously, IONSIV® IE-911 (batch 38-B) was used to remove ${ }^{137}$ Cs from SRS Tank 43H supernatant and its simulant (Gephart 1997). In these SRS batch tests, the cesium distribution ratio (D) with the actual tank waste was $1100 \mathrm{~mL} / \mathrm{g}$, while the $D$ value with the simulant was $1500 \mathrm{~mL} / \mathrm{g}$. These results demonstrated that IONSIV® IE-911 can be very effective in cesium removal. Currently, SRS personnel are performing batch and column tests on IONSIV® IE-911 (batch 4) with a simulant of the "average" SRS supernatant. At ORNL, the simulant of the "average" SRS supernatant was aiso used in the batch tests with IONSIV $\circledast$ IE-911 from batches 1,3 , and 4 . It should be noted that 
UOP, the manufacturer of IONSIV® IE-911, has produced the engineered form of CST in at least five different batches. Consequently, one of the objectives of this work was to determine the variability between the different batches.

The effects of particle size, organics, and variations in the treatment of the CST prior to testing were also evaluated during this study. This evaluation required several modifications to the CST or to the supernatant simulant prior to the start of the batch tests. In a few of the tests, "as received" CST was used, while most of the tests used "treated" CST, which was soaked in $\mathrm{NaOH}$, rinsed with $\mathrm{H}_{2} \mathrm{O}$, and air dried prior to the tests. In an effort to determine the effects of fines, a portion of the CST was sieved, and CST particles between 300 and $600 \mu \mathrm{m}$ were used in a few of the batch tests. In other tests, dibutylphosphate (DBP) was added to a portion of the supernatant simulant to determine the effect of $2000 \mathrm{mg} \mathrm{DBP} / \mathrm{L}$ on the performance of CST. In summary, the D results of IONSIV $\circledast$ IE-911 for cesium at 24,72 , and $144 \mathrm{~h}$ were measured under the following conditions:

1. batches 1 and 4 - "as received";

2. batches 1,3 , and 4 - "treated";

3. batch 4 - "as received" and "treated" - particle size of 300 to $600 \mu \mathrm{m}$; and

4. batch 4 - "treated" - DBP in the supernatant.

In addition to the $\mathrm{D}$ tests, the maximum concentration of soluble strontium in the "average" SRS simulant was determined. An excess amount of strontium with a trace amount of ${ }^{85} \mathrm{Sr}$ was added to a different aliquot of the supernatant simulant and allowed to equilibrate over several days. The concentration of ${ }^{85} \mathrm{Sr}$ in the simulant was monitored with a gamma counter until the strontium concentration had reached equilibrium.

This report presents the ORNL results from the strontium and CST distribution ratio tests with the simulated SRS supernatant. 


\section{SAMPLES}

\subsection{IONSIV@ IE-911}

CSTs are a new class of inorganic ion exchangers invented and developed through a collaborative effort between Sandia National Laboratories (SNL) and Texas A\&M University. The composition of CST is proprietary, and no information on the specifics of CST synthesis or composition is known. CST is produced as a very fine powder that could be used in a batch process, but it is not suitable for use in an ion-exchange column. An engineered form of CST, IONSIV® IE-911, was developed by UOP, Des Plaines, Illinois, under a Cooperative Research and Development Agreement with SNL. During the Cesium Removal Demonstration at ORNL, columns of IONSIV $₫$ IE-911 successfully removed cesium from more than 25,000 gal of tank supernatant (Walker et al. 1998).

\subsection{SIMULANT OF THE “AVERAGE" SRS SUPERNATANT}

The recipe for the simulant of the "average" SRS supernatant, which is found in the appendix, was provided by SRS personnel. The SRS simulant was made in 0.5 and $1 \mathrm{~L}$ batches. After the simulant solutions were prepared, they were spiked with ${ }^{137} \mathrm{Cs}$ so the cesium concentration in the solutions could be monitored with a gamma counter. Even though the solutions were thoroughly mixed with magnetic stir bars, a small amount of fine white solids was observed. Equilibrium calculations indicate that these solids should include gibbsite, $\mathrm{Al}_{2} \mathrm{O}_{3} \cdot 3 \mathrm{H}_{2} \mathrm{O}$. After samples were mixed for 5 days, they were passed through a $0.45-\mu \mathrm{m}$ high-capacity in-line filter (Gelman Sciences), and the liquids were combined. The density of the composite supernatant was $1.254 \mathrm{~g} / \mathrm{mL}$, which is comparable to the density of the solutions before filtration. It should be noted that the $\mathrm{pH}$ of the composite before and after contact with the IONSIV® IE-911 was greater than 14.

A portion of the composite supernatant was used to prepare the sample with $2000 \mathrm{mg} / \mathrm{L}$ of DBP; $0.4058 \mathrm{~g}$ of DBP (Eastman Chemicals) was added to $200 \mathrm{~mL}$ of the composite simulant. It should be noted that the DBP sample contained $45 \%$ monobutylphosphate. Even though the supernatant with DBP was thoroughly mixed, an 
organic layer appeared on top of the solution. Therefore, the solution was satuarated, and the DBP concentration in the simulant was considerably less than $2000 \mathrm{mg} / \mathrm{L}$.

A different aliquot of the composite supernatant was used to determine the maximum concentration of strontium. In preparation of the stock solution with cold strontium, $0.1509 \mathrm{~g}$ of $\mathrm{Sr}\left(\mathrm{NO}_{3}\right)_{2}$ (J. T. Baker) was transferred to a $25-\mathrm{mL}$ volumetric flask, which was then filled with deionized water. The stock solution with ${ }^{85} \mathrm{Sr}$ was prepared from a $0.5 \mathrm{M} \mathrm{HCl}$ solution with ${ }^{85} \mathrm{Sr}$ (Nen Researcher Products), which was diluted by a factor of 50 with deionized water. The initial ${ }^{85} \mathrm{Sr}$ concentration in the hot strontium stock solution was $23.20 \mu \mathrm{Ci} / \mathrm{mL}$. Then, $0.300 \mathrm{~mL}$, or $0.3009 \mathrm{~g}$, of the cold strontium stock solution was combined with $0.300 \mathrm{~mL}$, or $0.2987 \mathrm{~g}$, of the hot stock solution. This solution was agitated with a vortex mixer for $1 \mathrm{~min}$. Next, the ${ }^{85} \mathrm{Sr}$ concentration was determined with the aid of the gamma counter. The solution with cold and hot strontium was then combined with $25 \mathrm{~mL}$ of the simulant. The strontium loaded simulant was then agitated with a vortex mixer for $1 \mathrm{~min}$. The initial concentration of strontium in the simulant was $29.3 \mathrm{ppm}$.

\section{EXPERIMENTAL PROCEDURES}

\subsection{Water Content}

The water contents in the "treated" CST (batches 1, 3, and 4) and "as received" CST (batches 1 and 4) were determined before the batch tests were initiated. Approximately $0.5 \mathrm{~g}$ of IONSIV® IE-911 was placed into a previously weighed aluminum foil boat. After the boat and the CST were weighed with a Mettler AE200 balance, they were heated at $105^{\circ} \mathrm{C}$ until the dried CST reached a constant weight. Before the dried CST was weighed, the hot boat was placed in a desiccator until the CST had cooled to ambient temperature. 


\subsection{Distribution Ratios}

The $\mathrm{D}$ measurements were made using batch equilibration tests and techniques, which were previously used with IONSIV® IE-911 (Davidson et al. 1998). Duplicate samples of CST and simulant were used for each of the test conditions. Approximately $0.21 \mathrm{~g}$ (batches 1 and 4) or $0.25 \mathrm{~g}$ (batch 3) of IONSIV® IE-911 was placed into a previously weighed $50-\mathrm{mL}$ Oak Ridge centrifuge tube with a sealing cap. The goal of this step was to place $0.200 \mathrm{~g}$ of CST (dry weight basis) into each tube. After the CST and tube were weighed, approximately $40 \mathrm{~mL}$ of the supernatant simulant was added to the centrifuge tube, which was weighed after the transfer. In the initial test plan, $50 \mathrm{~mL}$ of the simulant was to be added to each tube. However, a 50-mL Oak Ridge centrifuge tube cannot accomodate this volume. The volume of simulant was calculated from the specific gravity of the supernatant. The IONSIV $®$ IE-911 and the simulated supernatant were mixed with a Labquake ${ }^{\mathrm{TM}}$ shaker. The action of the mixer is a back-and-forth rocking motion that was set to rock from $-45^{\circ}$ to $+45^{\circ}$ from the horizontal plane at 20 cycles per minute. At the end of 24,72 , and $168 \mathrm{~h}$, the tubes were reweighed to check for leakage. The tubes were then centrifuged for $20 \mathrm{~min}$ at $2800 \mathrm{rpm}$ with an International Equipment Company Centra 7 tabletop centrifuge. A small aliquot $(3 \mathrm{~mL})$ was removed from each sample with a glass pipet and placed into a $15-\mathrm{mL}$ tube. The small aliquots were then filtered through $0.22-\mu \mathrm{m}$ nylon filters to remove any of the remaining fine particulates. The filtering system consists of a $20-\mathrm{mL}$ glass syringe, a luer-lock filter, and a short piece of Tygon® tubing. Samples $(0.5-1.0 \mathrm{~mL})$ of the filtered supernatants were pipetted into preweighed counting tubes for radiochemical analysis. The remaining liquid in the $15-\mathrm{mL}$ tube was set aside for subsequent tests as necessary. At the completion of all the transfers, the Oak Ridge centrifuge tube and the counting tubes were weighed. The volumes of the filtered supernatants in the $15-\mathrm{mL}$ and counting tubes were kept as small as possible to minimize changes to the ratio of liquids (milliliters) to solids (grams) during each test. The ${ }^{137} \mathrm{Cs}$ activity was determined using a LKB Wallac 1282 Compugamma Universal gamma counter. Samples were counted for $\mathbf{4 0} \mathrm{min}$, and an empty tube was counted so the background radiation could be determined and deducted from subsequent measurements. 
Finally, a control test was also run. Forty milliliters of supernatant was added to a $50-\mathrm{mL}$ polypropylene centrifuge tube and mixed for 24,72 , and $168 \mathrm{~h}$. No detectable change in the ${ }^{137} \mathrm{Cs}$ activity of the simulant was noted.

\subsection{Maximum Concentration of Soluble Strontium}

The strontium-loaded supernatant was mixed with a Labquake ${ }^{\mathrm{TM}}$ shaker.

Periodically, the sample was weighed to check for leaks. Then, a small sample of the supernantant was removed and filtered with a $0.22-\mu \mathrm{m}$ nylon filter. After the small sample was weighed, it was counted with a LKB Wallac 1282 Compugamma Universal gamma counter. Finally, the counted sample was returned to the rest of the supernatant, and the entire sample was weighed. This procedure continued until the ${ }^{85} \mathrm{Sr}$ concentration in the filtered samples no longer changed with time.

\section{Calculations}

The results of batch tests are reported as distribution ratio (D) and percent removal (\% R). These values are calculated in the following manner:

$$
\mathrm{D}=\left[\left(C_{\mathrm{i}}-C_{\mathrm{f}}\right) / C_{f}\right][\mathrm{V} / \mathrm{m}]
$$

and $\% \mathrm{R}=100\left[\left(C_{i}-C_{\mathrm{f}}\right) / C_{\mathrm{i}}\right]$, where $C_{i}$ and $C_{\mathrm{f}}$ are the initial and final counts of ${ }^{137} \mathrm{Cs}$ per gram of supernatant, respectively; $V$ is the volume of simulant in millimeters; and $m$ is the dry mass of the IONSIV 8 IE-911 in grams.

\section{RESULTS}

\subsection{Water Content}

The results from the water content experiments on IONSIV $®$ IE-911 are presented in Table 1. For batches 1 and 4 , the water contents were very comparable and were not significantly affected by the treatment with $\mathrm{NaOH}$ and $\mathrm{H}_{2} \mathrm{O}$. However, the water content 
in the "treated" batch 3 of IONSIV $\circledast$ IE-911 was significantly higher than in the other batches. This observation was confirmed with a second, larger test with IONSIV® IE911 (batch 3). The reason for this difference is not known; however, it is probably due to a change in the manufacturing process since the different batches of IONSIV $\otimes$ IE-911 were treated in the same manner. Finally, it should be noted that the dried IONSIV® IE911 quickly absorbs moisture even at ambient temperature.

Table 1. Water content in different batches of IONSIV $®$ IE-911

\begin{tabular}{ccccc}
\hline Batch number & Condition & Initial weight $(\mathrm{g})$ & Dry weight $(\mathrm{g})$ & Water content (\%) \\
\hline & & & & \\
1 & Treated & 0.5037 & 0.4794 & 4.82 \\
3 & As received & 0.5036 & 0.4761 & 5.46 \\
3 & Treated & 0.5041 & 0.4038 & 19.90 \\
4 & Treated & 0.9997 & 0.7967 & 20.31 \\
4 & Treated & 0.5025 & 0.4760 & 5.27 \\
\hline
\end{tabular}

\subsection{Distribution Ratios}

The $\mathbf{D}$ and $\% \mathrm{R}$ results from the batch equilibration tests are provided in Table 2. All of the $\mathrm{D}$ results were corrected for changes in the ratio of liquids (milliliters) to solids (grams) during the tests. In addition, the D values are based on the "dry" weight of the CST.

When the difference in the $\mathrm{D}$ results for the duplicate samples was quite large, the supernatant sample that was responsible for the low D value was gravity settled, refiltered, and recounted. In most cases, the difference in the $\mathrm{D}$ results between the duplicate samples was reduced significantly. Apparently, the second solid/liquid separation was more effective in the removal of very fine CST particles, which can be produced by particle collisions during the rocking process. Therefore, the effectiveness of the solid/liquid separation can have a dramatic impact on the D values at 24 and $72 \mathrm{~h}$. It must be noted that none of the 168-h samples required a second solid/liquid separation. 
Table 2. Batch adsorption data for the removal of ${ }^{137} \mathrm{Cs}$ from the simulant of the "average" SRS supernatant with IONSIV $®$ IE-911

\begin{tabular}{|c|c|c|c|c|c|c|c|c|c|}
\hline \multirow[b]{3}{*}{ Condition } & \multicolumn{9}{|c|}{ Mixing time $^{a}$} \\
\hline & \multicolumn{3}{|c|}{24} & \multicolumn{3}{|c|}{72} & \multicolumn{3}{|c|}{168} \\
\hline & $\mathrm{L} / \mathrm{S}$ & $\mathrm{D}$ & $\% \mathrm{R}$ & $\mathrm{L} / \mathrm{S}$ & $\mathrm{D}$ & $\% \mathrm{R}$ & $\mathrm{L} / \mathrm{S}$ & $\mathrm{D}$ & $\% \mathrm{R}$ \\
\hline \multicolumn{10}{|c|}{ Batch 1} \\
\hline Treated & 202 & 434 & 68.3 & 182 & $1538^{b}$ & $89.4^{b}$ & 175 & 2034 & 92.1 \\
\hline $\begin{array}{l}\text { Treated } \\
\text { (Average) }\end{array}$ & 202 & $\frac{365}{(400)}$ & $\frac{64.4}{(66.4)}$ & 188 & $\frac{1712}{(1625)}$ & $\frac{90.1}{(89.8)}$ & 182 & $\frac{2029}{(2032)}$ & $\frac{91.8}{(92.0)}$ \\
\hline As received & 196 & 675 & 77.5 & 177 & 2073 & 92.1 & 171 & 2238 & 92.9 \\
\hline $\begin{array}{l}\text { As received } \\
\text { (Average) }\end{array}$ & 206 & $\frac{596}{(636)}$ & $\frac{74.3}{(75.9)}$ & 179 & $\frac{2041}{(2051)}$ & $\frac{91.9}{(92.0)}$ & 172 & $\frac{2267}{(2253)}$ & $\frac{93.0}{(93.0)}$ \\
\hline \multicolumn{10}{|c|}{ Batch 3} \\
\hline Treated & 203 & $397^{b}$ & $66.1^{b}$ & 182 & 1162 & 86.5 & 175 & 1399 & 88.9 \\
\hline $\begin{array}{l}\text { Treated } \\
\text { (Average) }\end{array}$ & 204 & $\frac{387}{(392)}$ & $\frac{65.5}{(65.8)}$ & 188 & $\frac{1153}{(1158)}$ & $\frac{86.0}{(86.3)}$ & 181 & $\frac{1508}{(1454)}$ & $\frac{89.3}{(89.1)}$ \\
\hline \multicolumn{10}{|c|}{ Batch 4} \\
\hline Treated & 199 & 451 & 69.4 & 181 & 1234 & 87.2 & 175 & 1480 & 89.4 \\
\hline $\begin{array}{l}\text { Treated } \\
\text { (Average) }\end{array}$ & 202 & $\frac{363}{(407)}$ & $\frac{64.3}{(66.9)}$ & 180 & $\frac{1237}{(1236)}$ & $\frac{87.3}{(87.3)}$ & 173 & $\frac{1607}{(1544)}$ & $\frac{90.3}{(89.0)}$ \\
\hline As received & 206 & 592 & 74.2 & 187 & $1406^{b}$ & $88.2^{b}$ & 182 & 2175 & 92.3 \\
\hline $\begin{array}{l}\text { As received } \\
\text { (Average) }\end{array}$ & 198 & $\frac{703}{(648)}$ & $\frac{78.0}{(76.1)}$ & 184 & $\frac{1530}{(1468)}$ & $\frac{89.2}{(88.7)}$ & 177 & $\frac{2123}{(2149)}$ & $\frac{92.3}{(92.3)}$ \\
\hline Treated/sieved & 201 & 308 & 61.9 & 186 & $1644^{b}$ & $89.8^{b}$ & 177 & 1667 & 90.4 \\
\hline $\begin{array}{l}\text { Treated/sieved } \\
\text { (Average) }\end{array}$ & 201 & $\frac{337}{(323)}$ & $\frac{60.5}{(61.2)}$ & 185 & $\frac{1892}{(1768)}$ & $\frac{91.1}{(90.5)}$ & 177 & $\frac{1578}{(1623)}$ & $\frac{89.9}{(90.2)}$ \\
\hline As received/sieved & 205 & $371^{b}$ & $64.4^{b}$ & 178 & 1262 & 87.6 & 169 & 1818 & 91.5 \\
\hline $\begin{array}{l}\text { As received/sieved } \\
\text { (Average) }\end{array}$ & 205 & $\frac{546}{(459)}$ & $\frac{72.7}{(68.6)}$ & 188 & $\frac{1709}{(1486)}$ & $\frac{90.1}{(88.9)}$ & 185 & $\frac{1881}{(1850)}$ & $\frac{91.1}{(91.3)}$ \\
\hline Treated/DBP & 194 & 525 & 73.0 & 175 & $1395^{b}$ & $88.8^{b}$ & 168 & 1567 & 90.3 \\
\hline $\begin{array}{l}\text { Treated/DBP } \\
\text { (Average) }\end{array}$ & 196 & ${\frac{423^{b}}{(474)}}^{b}$ & $\frac{68.4^{b}}{(70.7)}$ & 173 & $\frac{1498}{(1447)}$ & $\frac{89.7}{(89.3)}$ & 166 & $\frac{1490}{(1529)}$ & $\frac{90.0}{(90.2)}$ \\
\hline
\end{tabular}


The generation of fine CST particles during rocking process was validated in other batch tests. At the end of each mixing period, each sample was centrifuged at 2800 rpm, and a portion of the supernatant was pipetted into a separate tube. Then, part of this smaller sample was filtered and counted. The remainder of the centrifuged and unfiltered liquid was set aside for a minimum of 1 week. Portions of three of these samples were then filtered and counted. The ${ }^{137} \mathrm{Cs}$ concentration in each sample was on average $75 \%$ lower than in its counterpart from a week earlier. These results clearly indicate that the rocking process produces fine CST particles, which can remain in suspension even after centrifugation at $2800 \mathrm{rpm}$. Higher-speed centrifugation may be needed to remove these particles after mixing. In addition, the dramatic cesium removal by very fine particles, which could not be visually detected, indicates that most of the cesium capacity in the large IONSIV $\circledast$ IE-911 particles is not being utilized in these tests.

\subsection{Maximum Concentration of Soluble Strontium}

The initial concentration of strontium in the simulant of the "average" SRS supernatant was $29.3 \mathrm{ppm}$. It was expected that very little of the strontium in the sample would remain soluble. In fact, only $6 \%$ of the strontium remained soluble after 2 days. Over the next several days, the concentration of strontium continued to decline. After 10 days, the concentration was $0.42 \mathrm{ppm}$. The strontium concentrations at 13 and 15 days indicated that the sample had reached equilibrium. The maximum concentration of soluble strontium in the "average" SRS supernatant was determined to be $0.37 \mathrm{ppm}$. The presence of strontium in the supernatant has been shown to reduce the performance of the CST. However, this low concentration of strontium should not be a significant factor.

\section{DISCUSSION}

\subsection{Particle Size}

The highest $\mathrm{D}$ results at $168 \mathrm{~h}$ were observed with the "as received" samples. This difference in D results is primarily due to smaller particles and fines in the "as received" 
samples. The average 168-h D for the "as received/sieved" samples (batch 4) was 299 lower than its "as received" counterpart. Most of the observable particles removed by the sieving process were smaller than $300 \mu \mathrm{m}$, and the sieving process is also expected to remove fines. Similarly, the treatment process with $\mathrm{NaOH}$ and $\mathrm{H}_{2} \mathrm{O}$ was effective in the removal of the smaller particles and fines. However, the difference between the average 168-h D values for the "as received" and "treated" samples (batch 4) was much greater. In addition to removal of smaller particles, the $\mathrm{NaOH}$ and $\mathrm{H}_{2} \mathrm{O}$ treatment slightly increased the average particle size, and these results indicate that small increases in particle sizes can significantly slow kinetics and reduce D values. The effort to sieve the "treated" sample (batch 4) was ineffective, and the average 168-h D values for "treated" and "treated/sieved" samples (batch 4) were comparable. All of these results showed that the kinetics and performance of IONSIV® IE-911 can be significantly impacted by sample preparation.

A comparison of the 168-h D results between the different batches of IONSIV $®$ IE-911 showed that the variability in performance increased dramatically after the samples were treated with $\mathrm{NaOH}$ and $\mathrm{H}_{2} \mathrm{O}$. The difference in the average $168-\mathrm{h} \mathrm{D}$ values for the "as received" samples (batches 1 and 4) was only 104. However, after the $\mathrm{NaOH}$ and $\mathrm{H}_{2} \mathrm{O}$ treatment, the average $168-\mathrm{h} \mathrm{D}$ difference between these batches was 488 . In both cases, the performance of batch 1 was superior to that of batch 4 . This surprising result is probably due to a change in the particle size distribution between the two batches. It should be noted that the difference in performance between the "treated" samples (batches 3 and 4) was small. Therefore, the results of the latter batches of IONSIV® IE-911 appear to be more consistent.

\subsection{Effects of Dibuytlphosphate}

The average 168-h D results for the "treated" samples (batch 4) and the "treated/DBP" samples (batch 4) were comparable. Therefore, the DBP did not adversely affect the performance of the CST in this batch operation. However, the possilibility of DBP fouling during column operations cannot be ruled out. The solubility of DBP in the 
simulant was much lower than $2000 \mathrm{mg} / \mathrm{L}$ since an organic layer on top of the supernatant simulant was observed. Therefore, the amount of contact between the DBP and IONSIV@ IE-911 was very limited. A more severe test of the potential fouling by DBP would have involved a direct contact of DBP with the IONSIV@ IE-911 prior to the batch test.

\subsection{Actual Vs Predicted Equilibrium D Values}

Staff members at Texas A\&M University (Zheng et al. 1997) have developed a model to predict the equilibrium $\mathrm{D}$ value for a given waste stream. Based on the composition of the "average" SRS supernatant, the model predicted that the equilibrium D values at 25 , 26 , and $30^{\circ} \mathrm{C}$ would be 2340,2280 , and $2060 \mathrm{~mL} / \mathrm{g}$, respectively. The $168-\mathrm{h} \mathrm{D}$ results with "as received" samples were very close to the predicted values. These calculations also show that the small increases in temperature can significantly reduce the performance of IONSIV $®$ IE-911. The temperature effect in the model is based on very limited experimental data, which ranged from 25 to $43^{\circ} \mathrm{C}$. It should also be noted that attempts to use the model on the "average" SRS supernatant at slightly higher temperatures were unsuccessful.

\section{CONCLUSIONS}

The $D$ values clearly indicated that IONSIV $®$ IE-911 can be very effective in the removal of cesium from the simulant of the "average" SRS supernatant. The variability between the different production runs of IONSIV $\circledast$ IE-911 was very small. However, the variability between the different batches of IONSIV® IE-911 increased after the CST had been treated with $\mathrm{NaOH}$ and then $\mathrm{H}_{2} \mathrm{O}$. The 168-h D values for the "treated" samples ranged from 1454 to $2032 \mathrm{~mL} / \mathrm{g}$. The predicted $\mathrm{D}$ values from the equilibrium model were very comparable to the experimental results with the "as received" samples of CST. The model was also used to demonstrate that increases in temperature can significantly reduce the performance of the IONSIV (B IE-911. The equilibrium model predicted that 
an increase in temperature from 25 to $30^{\circ} \mathrm{C}$ would reduce the $\mathrm{D}$ value from 2340 to $2060 \mathrm{~mL} / \mathrm{g}$. Similarly, increases in the particle sizes adversely affected the D values. The D values for the "sieved" and "treated" samples were signicantly lower than their "as received" counterparts because the sieving and the treatment process with $\mathrm{NaOH}$ and $\mathrm{H}_{2} \mathrm{O}$ removed fines, which were in the "as received" sample. The treatment process also increased the average particle size, which led to a further reduction in the performance of IONSIV@ IE-911. However, the presence of the organics in the form of DBP and monobutylphosphate did not impact the $\mathrm{D}$ results.

Finally, the maximum concentration of soluble strontium in the simulant of the "average" SRS supernatant was $0.37 \mathrm{ppm}$. This low concentration of strontium should not significantly reduce the performance of the CST.

\section{ACKNOWLEDGMENTS}

This work was funded by the U.S. Department of Energy through the High Level Waste Management Division of the Westinghouse Savannah River Company (WSRC) and by the Office of Science and Technology's Accelerated Site Technology Deployment Initiative. The authors would like to thank W. L. Tamosaitis of WSRC and C. P. McGinnis of the Tanks Focus Area for their support and guidance.

\section{REFERENCES}

Davidson, D. J., J. L. Collins, K. K. Anderson, C. W. Chase, and B. Z. Egan, Removal of Cesium, Technetium, and Strontium from Tank Waste Supernatant, ORNL/TM-13612, Lockheed Martin Energy Research Corporation, Oak Ridge National Laboratory, August 1998.

Gephart, J. M. (Editor), Proceedings of the Efficient Separations and Processing Crosscutting Program 1997 Technical Exchange Meeting, PNNL-SA-28461, Rev. 1, Battelle Corporation, Pacific Northwest National Laboratory, 1997. 
Walker, J. F., Jr., P. A. Taylor, R. L. Cummins, B. S. Evans, S. D. Heath, J. D. Hewitt, R. D. Hunt, H. L. Jennings, J. A. Kirby, D. D. Lee, S. Lewis-Lambert, S. A. Richardson, and R. F. Utrera, Cesium Removal Demonstration Utilizing Crystalline Silicotitanate Sorbent for Processing Melton Valley Storage Tank Supernate: Final Report, ORNL/TM-13503, Lockheed Martin Energy Research Corporation, Oak Ridge National Laboratory, March 1998.

Zheng, Z., R. G. Anthony, and J. E. Miller, "Modeling Multicomponent Ion Exchange Equilibrium Utilizing Hydrous Crystalline Silicotitanates by a Multiple Interactive Ion Exchange Site Model," Ind. Eng. Chem. Res. 36, 2427-2434 (1997). 


\section{APPENDIX}

Worksheets for the Preparation of the Simulant for the "Average" SRS Supernatant

Part A (0.43 M CsCl stock solution)

1. Locate a dry 50-mL volumetric flask.

2. Add the $\mathrm{CsCl}$ to the flask, followed by about $25 \mathrm{~g}$ of water. Mix to dissolve the solid.

3. Finish filling to the line with water and mix briefly.

4. Store the solution in the glass flask.

Date: $\underline{9 / 14 / 98}$ Name: Rodney Hunt Balance: Mettler AE200

TABLE 1

Chemical Manufacturer and lot number used Req'd (g) Amount (g)

$\mathrm{CsCl}$ Chemetall 403/44 3.66197

Part B (average solution)

1. Locate a dry 1-L volumetric flask. Weigh the empty flask with the stopper.

2. Weigh the $\mathrm{NaOH}$ (Table 2) into the flask. Add $500 \mathrm{~g}$ of water, and dissolve the $\mathrm{NaOH}$ before continuing. Caution! Caustic solution.

Note: If the solution is too hot to handle safely, cool it before proceeding.

3. Add the aluminum nitrate, $\mathrm{Al}\left(\mathrm{NO}_{3}\right)_{3} \cdot 9 \mathrm{H}_{2} \mathrm{O}$, to the flask and mix to dissolve.

Note: Do not add sodium nitrite $\left(\mathrm{NaNO}_{2}\right)$ prior to dissolving the aluminum nitrate in excess $\mathrm{NaOH}$. Poisonous red $\mathrm{NO}_{2}$ gas could form.

4. Add the remaining chemicals in Table 2 followed by about $250 \mathrm{~g}$ of water.

5. Pipet $0.33 \mathrm{~mL}$ of the cesium solution from Part $B$ into the $1-\mathrm{L}$ flask or pipet $0.16 \mathrm{~mL}$ of the cesium solution into the $0.5-\mathrm{L}$ flask.

6. Mix for $1-2 \mathrm{~h}$ until the solids have dissolved.

Note: Minor amounts of solid may not dissolve, leaving the solution cloudy. Do not be concerned.

7. Finish filling to the line with water and mix briefly.

8. Reweigh the flask of salt solution with the stopper. Calculate the density. 
Date: 9/11/98 Name: Rodney Hunt

Wt of empty flask (1-L) and stopper:

Wt of partially filled flask and stopper:

Density of solution:
$261.76 \mathrm{~g}$

$1514.6 \mathrm{~g}$

$1.2528 \mathrm{~g} / \mathrm{mL}$

TABLE 2

Chemical

$\mathrm{NaOH}$

$\mathrm{Al}\left(\mathrm{NO}_{3}\right)_{3} \cdot 9 \mathrm{H}_{2} \mathrm{O}$

$\mathrm{NaNO}_{3}$

$\mathrm{NaNO}_{2}$

$\mathrm{Na}_{2} \mathrm{CO}_{3}$

$\mathrm{Na}_{2} \mathrm{SO}_{4}$

$\mathrm{NaCl}$

$\mathrm{NaF}$

$\mathrm{Na}_{2} \mathrm{C}_{2} \mathrm{O}_{4}$

$\mathrm{Na}_{2} \mathrm{HPO}_{4} \cdot 7 \mathrm{H}_{2} \mathrm{O}$

$\mathrm{Na}_{2} \mathrm{SiO}_{3} \cdot 5 \mathrm{H}_{2} \mathrm{O}$

$\mathrm{NaMoO}_{4} \cdot 2 \mathrm{H}_{2} \mathrm{O}$

$\mathrm{KNO}_{3}$
Manufacturer and lot number used

EM Science 35122527

Fisher Scientific

EM Science 35030509

J. T. Baker L32624

Fisher Scientific 741606

MCB Al0J12

Fisher Scientific 725324

Fisher Scientific 725324

J. T. Baker

Fisher Scientific

EM Science 36127634

MCB

EM Science 34320533
Req'd (g) Amount (g)

$125.871 \quad \underline{125.853}$

$116.293 \quad \underline{116.294}$

$103.943 \quad \underline{103.946}$

$35.190 \quad \underline{35.191}$

$16.961 \quad 16.962$

$21.306 \quad \underline{21.305}$

$1.461 \quad 1.462$

$1.343 \quad 1.343$

$1.072 \quad 1.071$

$2.681 \quad 2.682$

$0.779 \quad 0.780$

$0.048 \quad \underline{0.048}$

1.517 
Date: 9/11/98 Name: Rodney Hunt Balance: Mettler AE200

Wt of empty flask (0.5-L) and stopper: $191.35 \mathrm{~g}$

Wt of partially filled flask and stopper: $1514.6 \mathrm{~g}$

Density of solution: $1.2535 \mathrm{~g} / \mathrm{mL}$

TABLE 2

\begin{tabular}{|c|c|c|c|}
\hline Chemical & Manufacturer and lot number used & Req'd (g) & Amount ( $g$ \\
\hline $\mathrm{NaOH}$ & EM Science 35122527 & $125.871 / 2$ & 62.931 \\
\hline $\mathrm{Al}\left(\mathrm{NO}_{3}\right)_{3} \cdot 9 \mathrm{H}_{2} \mathrm{O}$ & Fisher Scientific & $116.293 / 2$ & 58.148 \\
\hline $\mathrm{NaNO}_{3}$ & EM Science 35030509 & $103.943 / 2$ & 51.975 \\
\hline $\mathrm{NaNO}_{2}$ & J. T. Baker L32624 & $35.190 / 2$ & 17.594 \\
\hline $\mathrm{Na}_{2} \mathrm{CO}_{3}$ & Fisher Scientific 741606 & $16.961 / 2$ & 8.481 \\
\hline $\mathrm{Na}_{2} \mathrm{SO}_{4}$ & $\mathrm{MCB}$ Al0J12 & $21.306 / 2$ & 10.655 \\
\hline $\mathrm{NaCl}$ & Fisher Scientific 725324 & $1.461 / 2$ & 0.732 \\
\hline $\mathrm{NaF}$ & Fisher Scientific 725324 & $1.343 / 2$ & 0.672 \\
\hline $\mathrm{Na}_{2} \mathrm{C}_{2} \mathrm{O}_{4}$ & J. T. Baker & $1.072 / 2$ & 0.535 \\
\hline $\mathrm{Na}_{2} \mathrm{HPO}_{4} \cdot 7 \mathrm{H}_{2} \mathrm{O}$ & Fisher Scientific & $2.681 / 2$ & 1.342 \\
\hline $\mathrm{Na}_{2} \mathrm{SiO}_{3} \cdot 5 \mathrm{H}_{2} \mathrm{O}$ & EM Science 36127634 & $0.779 / 2$ & $\underline{0.390}$ \\
\hline $\mathrm{NaMoO}_{4}-2 \mathrm{H}_{2} \mathrm{O}$ & MCB & $0.048 / 2$ & 0.023 \\
\hline $\mathrm{KNO}_{3}$ & EM Science 34320533 & $1.517 / 2$ & 0.759 \\
\hline
\end{tabular}


ORNL/TM-13740

\section{INTERNAL DISTRIBUTION}

$\begin{aligned} \text { 1. } & \text { K. K. Anderson } \\ 2 . & \text { E. C. Beahm } \\ 3 . & \text { J. L. Collins } \\ \text { 4-13. } & \text { R. D. Hunt } \\ \text { 14. } & \text { R. T. Jubin } \\ \text { 15. } & \text { T. E. Kent } \\ \text { 16. } & \text { D. D. Lee } \\ 17 . & \text { C. P. McGinnis }\end{aligned}$

18. L. E. McNeese

19. P. A. Taylor

20. J. S. Watson

21. T. D. Welch

22. Central Research Library

23. ORNL Laboratory Records - RC

24-25. ORNL Laboratory Records - OSTI

\section{EXTERNAL DISTRIBUTION}

26. Ray Anthony, Texas A\&M University, Department of Chemical Engineering, College Station, TX 77843-3122

27. Sam Fink, Westinghouse Savannah River Company, Savannah River Technology Center, Building 773-A, Room B-1 12, Aiken, SC 29808

28. Bill King, Westinghouse Savannah River Company, Savannah River Technology Center, Building 773-41A, Room 274, Aiken, SC 29808

29. Dan McCabe, Westinghouse Savannah River Company, Savannah River Technology Center, Building 773-43A, Room 218, Aiken, SC 29808

30. Michael Poirier, Westinghouse Savannah River Company, Savannah River Technology Center, Building 773-42A, Room 152, Aiken, SC 29808

31. Walt Tamosaitis, Westinghouse Savannah River Company, Savannah River Technology Center, Building 773-A, Room A-231, Aiken, SC 29808

32. Bill Van-Pelt, Westinghouse Savannah River Company, Savannah River Technology Center, Building 679-T, Room 2A3, Aiken, SC 29808

33. Doug Walker, Westinghouse Savannah River Company, Savannah River Technology Center, Building 773-A, Room B-124, Aiken, SC 29808

34. Linda Wang, Purdue University, School of Chemical Engineering, West Lafayette, IN 47907-1283 